\title{
An extensively hydrolysed casein-based formula for infants with cows' milk protein allergy: tolerance/hypo-allergenicity and growth catch-up
}

\author{
Christophe Dupont ${ }^{1 *}$, Jeroen $\mathrm{Hol}^{2}$, Edward E. S. Nieuwenhuis ${ }^{3}$ and the Cow's Milk Allergy Modified \\ by Elimination and Lactobacilli study group ${ }^{4} \dagger$ \\ ${ }^{1}$ Department of Pediatric Gastroenterology, Hepatology and Nutrition, Service d'Explorations Fonctionnelles \\ Digestives Pédiatriques, Hôpital Necker-Enfants Malades, 149 rue de Sèvres, 75015 Paris, France \\ ${ }^{2}$ Department of Pediatrics, St Elisabeth Hospital, Willemstad, Curaçao, The Netherlands Antilles \\ ${ }^{3}$ Department of Pediatrics, Wilhelmina Children's Hospital, University Medical Center Utrecht, Utrecht, The Netherlands \\ ${ }^{4}$ Gouda and Rotterdam, The Netherlands
}

(Submitted 21 May 2014 - Final revision received 30 September 2014 - Accepted 25 December 2014 - First published online 17 March 2015)

\section{Abstract}

Children with cows' milk protein allergy (CMPA) are at risk of insufficient length and weight gain, and the nutritional efficacy of hypoallergenic formulas should be carefully assessed. In 2008, a trial assessed the impact of probiotic supplementation of an extensively hydrolysed casein-based formula (eHCF) on acquisition of tolerance in 119 infants with CMPA. First analysis of the study results showed that the studied formula allowed improvement of food-related symptoms. The scoring of atopic dermatitis (SCORAD) index was assessed at randomisation and after 6 months of feeding. A post hoc analysis was performed using WHO growth software's nutritional survey module (WHO Anthro version 3.2.2). All infants who were fed the study formula tolerated it well. The SCORAD index significantly improved from randomisation to 6 months of feeding with the study formula. Anthropometric data indicated a significant improvement in the weight-for-age, length-for-age and weight-for-length $z$ scores, as well as in the restoration of normal BMI. The probiotic supplementation did not show any impact on these parameters. The present data showed that this eHCF was clinically tolerated and significantly improved the SCORAD index and growth indices.

\section{Key words: Anthropometric data: Infant development: Scoring of atopic dermatitis: Hypo-allergenic formulas}

Cows' milk (CM) proteins are the most frequent cause of food allergy during infancy. Depending on diagnostic criteria and study design, estimates of the prevalence of cows' milk protein allergy (CMPA) vary from 2 to $7 \cdot 5 \%{ }^{(1)}$.

The first-line treatment for food allergy disorders is avoidance of the suspected allergen. In the particular case of CMPA, guidelines recommend the use of formulas in which $\mathrm{CM}$ proteins are extensively hydrolysed ${ }^{(1,2)}$. By reducing the number of conformational and sequential epitopes, extensive hydrolysis dramatically reduces allergenicity of CM proteins. This avoidance of contact to allergens is the primary objective of using extensively hydrolysed formulas and most often allows infants to thrive while progressively outgrowing CMPA. Thus, hypo-allergenic formulas should ensure a normal development of the infant; however, data relating to the impact of these formulas on infants' growth are insufficient ${ }^{(3-5)}$.
In 2008, the Cow's Milk Allergy Modified by Elimination and Lactobacilli (CAMEL) study was a randomised, doubleblind, placebo-controlled trial, funded by the Dutch Ministry of Economic Affairs, that aimed at determining whether acquisition of tolerance to $\mathrm{CM}$ would be affected by supplementation to the infant formula with a combination of two probiotics (Lactobacillus casei CRL431 and Bifidobacterium lactis Bb-12) ${ }^{(6)}$. This study included 119 allergic infants fed with an extensively hydrolysed casein-based formula (eHCF) either supplemented with probiotics or without probiotics for 6 months. The probiotic supplementation did not improve acquisition of tolerance. However, although collected, the data concerning tolerance of the formula and growth parameters of all infants included in the study did not appear in the initial analysis.

Therefore, the objective of this post hoc analysis was to capitalise on the data pertaining to a population of infants

\footnotetext{
Abbreviations: AD, atopic dermatitis; CAMEL, Cow's Milk Allergy Modified by Elimination and Lactobacilli; CM, cows' milk; CMPA, cows' milk protein allergy; DBPCFC, double-blind, placebo-controlled food challenge; eHCF, extensively hydrolysed casein-based formula; SCORAD, scoring of atopic dermatitis
}

*Corresponding author: C. Dupont, fax +331444925 96, email christophe.dupont@nck.aphp.fr

† See the Appendix for a full list of the CAMEL study group members. 


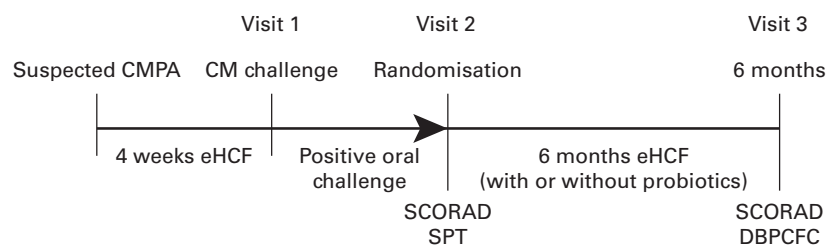

Fig. 1. Design of the study adapted from the Cow's Milk Allergy Modified by Elimination and Lactobacilli study ${ }^{(6)}$. CMPA, cows' milk protein allergy; eHCF, extensively hydrolysed casein-based formula; CM, cows' milk; SCORAD, scoring of atopic dermatitis; SPT, skin prick test; DBPCFC, double-blind, placebo-controlled food challenge.

with validated CMPA in order to assess the tolerance/ hypo-allergenicity of the formula along with its safety for growth in infants fed this eHCF for 6 months.

\section{Methods \\ Population and design}

The present randomised, double-blind, placebo-controlled study enrolled infants with a diagnosis of CMPA, aged less than 6 months, followed up by the paediatricians of the CAMEL study group. The present study was conducted according to the guidelines laid down in the Declaration of Helsinki, and all procedures involving human subjects were approved by the local ethics committee of the Erasmus MC, Rotterdam. At least, one parent in each family provided written informed consent before inclusion.

\section{Interventions}

Details of the procedure have been described previously ${ }^{(6)}$. In brief, upon identification, infants with suspected CMPA were prescribed an eHCF for at least 4 weeks (Fig. 1). Following this, CMPA was then confirmed at visit 1 using a food challenge performed according to the current guidelines ${ }^{(7,8)}$. All infants with positive challenge were randomised at visit 2 (inclusion visit) to the supplemented or the non-supplemented eHCF group. Skin prick tests against milk, egg and soya were performed at visit 2, and a double-blind, placebo-controlled food challenge (DBPCFC) was performed after 6 months of eHCF feeding (visit 3).

\section{Study products}

The eHCF was a commercially available formula especially designed for infants with CMPA (Allernova, Allergy Care; United Pharmaceuticals). The probiotic-supplemented formula used the same eHCF but with L. casei CRL 431 and B. lactis Bb-12. Nutritional composition of the eHCF conforms to the essential composition set by the European Directive 1999/21 for foods for special medical purposes and by the European Directive 2006/141 for infant and follow-on formulas, particularly regarding the amino acid profile. The energy content in the formula is $276.9 \mathrm{~kJ} /$ $100 \mathrm{ml}(66.3 \mathrm{kcal} / 100 \mathrm{ml})$, and the protein, lipid and carbohydrate contents are $1.6,3.5$ and $7.2 \mathrm{~g} / 100 \mathrm{ml}$, respectively.
The extensive casein hydrolysate has a median peptide size of $267 \mathrm{Da}$, with more than $95 \%$ of peptides less than $1500 \mathrm{Da}$.

\section{Measurements}

Allergic symptoms were registered after food challenge, at visits 1 and 3. The scoring of atopic dermatitis (SCORAD) index, assessing the severity of the eczema, was measured at visits 2 and $3^{(9)}$. Weight and length were measured at visits 2 and 3. Weight-for-age, length-for-age, weight-for-length and BMI-for-age $z$ scores were computed for each infant, based on the WHO 2006 reference data ${ }^{(10)}$.

\section{Statistical analyses}

Normality of distributions was assessed using the Shapiro-Wilk test. Quantitative parameters were compared within groups between visit 2 (randomisation) and visit 3 using Student's $t$ test (normally distributed data) or Wilcoxon's test (nonnormally distributed data), and were compared between groups using ANCOVA based on ranks with the baseline value as a co-variable. Statistical analyses were conducted using SAS version 9.2 (SAS Institute Inc.). Statistical tests were two-sided, and the level of significance was set at $5 \%$. Sample size calculation showed that ninety-seven patients were required to demonstrate an increase of +0.5 in the weight-for-age $z$ score, considering $1.5 \mathrm{SD}$ and assuming a type-I error of $5 \%$ and a power of $90 \%{ }^{(3)}$. Distributions of $z$ scores compared with normal reference values were represented using WHO Anthro version 3.2.2 software.

\section{Results}

\section{Study population}

Of the 193 infants with suspected CMPA referred to the CAMEL study, 119 met the criteria to continue the study following

Table 1. Baseline characteristics of included infants

(Mean values and standard deviations; number of subjects and percentages)

\begin{tabular}{|c|c|c|c|c|c|c|}
\hline & \multicolumn{2}{|c|}{$\begin{array}{l}\text { eHCF } \\
(n 60)\end{array}$} & \multicolumn{2}{|c|}{$\begin{array}{c}\text { eHCF + } \\
\text { probiotics } \\
\quad(n 59)\end{array}$} & \multicolumn{2}{|c|}{$\begin{array}{c}\text { Total } \\
(n 119)\end{array}$} \\
\hline & $n$ & $\%$ & $n$ & $\%$ & $n$ & $\%$ \\
\hline Boys & 36 & $60 \cdot 0$ & 30 & $50 \cdot 8$ & 66 & $55 \cdot 5$ \\
\hline \multicolumn{7}{|l|}{ Age at inclusion (months) } \\
\hline Mean & \multicolumn{2}{|c|}{$4 \cdot 1$} & \multicolumn{2}{|c|}{$4 \cdot 3$} & \multicolumn{2}{|c|}{$4 \cdot 2$} \\
\hline SD & \multicolumn{2}{|c|}{1.5} & \multicolumn{2}{|c|}{$1 \cdot 2$} & \multicolumn{2}{|c|}{$1 \cdot 4$} \\
\hline \multicolumn{7}{|l|}{ Birth weight $(\mathrm{g})$} \\
\hline Mean & \multicolumn{2}{|c|}{3445} & \multicolumn{2}{|c|}{3456} & \multicolumn{2}{|c|}{3451} \\
\hline SD & \multicolumn{2}{|c|}{556} & \multicolumn{2}{|c|}{504} & \multicolumn{2}{|c|}{529} \\
\hline \multicolumn{7}{|l|}{ Gestational age (weeks) } \\
\hline Mean & \multicolumn{2}{|c|}{$39 \cdot 6$} & \multicolumn{2}{|c|}{$39 \cdot 5$} & \multicolumn{2}{|c|}{$39 \cdot 6$} \\
\hline SD & \multicolumn{2}{|c|}{1.7} & \multicolumn{2}{|c|}{$1 \cdot 6$} & \multicolumn{2}{|c|}{1.6} \\
\hline Caesarean delivery & 10 & $16 \cdot 7$ & 12 & $20 \cdot 7$ & 22 & $18 \cdot 6$ \\
\hline Positive SPT against milk & 12 & $20 \cdot 7$ & 6 & $10 \cdot 3$ & 18 & $15 \cdot 5$ \\
\hline Positive SPT against egg & 13 & $22 \cdot 4$ & 10 & $17 \cdot 2$ & 23 & $19 \cdot 8$ \\
\hline Positive SPT against soya & 2 & 3.4 & 1 & $1 \cdot 7$ & 3 & $2 \cdot 6$ \\
\hline
\end{tabular}

eHCF, extensively hydrolysed casein-based formula; SPT, skin prick test. 
Table 2. Symptoms that developed during oral food challenge at visit 1 by allergic infants (Number of subjects and percentages)

\begin{tabular}{|c|c|c|c|c|c|c|c|}
\hline & & \multicolumn{2}{|c|}{ eHCF $(n 59)$} & \multicolumn{2}{|c|}{$\begin{array}{c}\text { eHCF + } \\
\text { probiotics ( } n 59)\end{array}$} & \multicolumn{2}{|c|}{ Total $(n 118)$} \\
\hline & & $n$ & $\%$ & $n$ & $\%$ & $n$ & $\%$ \\
\hline \multirow[t]{4}{*}{ Skin symptoms } & Urticaria & 3 & $5 \cdot 1$ & 4 & $6 \cdot 8$ & 7 & 5.9 \\
\hline & Rash & 31 & $52 \cdot 5$ & 24 & $40 \cdot 7$ & 55 & $46 \cdot 6$ \\
\hline & Pruritus & 6 & $10 \cdot 2$ & 10 & $16 \cdot 9$ & 16 & $13 \cdot 6$ \\
\hline & Eczema & 5 & 8.5 & 8 & $13 \cdot 6$ & 13 & $11 \cdot 0$ \\
\hline \multirow[t]{2}{*}{ Gastrointestinal symptoms } & Vomiting & 16 & $27 \cdot 1$ & 14 & 23.7 & 30 & 25.4 \\
\hline & Diarrhoea & 9 & $15 \cdot 2$ & 6 & $10 \cdot 2$ & 15 & $12 \cdot 7$ \\
\hline \multirow[t]{2}{*}{ Respiratory symptoms } & Sneezing & 0 & 0.0 & 0 & 0.0 & 0 & 0.0 \\
\hline & Wheezing & 1 & $1 \cdot 7$ & 2 & 3.4 & 3 & 2.5 \\
\hline Subjective symptoms (crying and irritability) & & 27 & $45 \cdot 8$ & 25 & $42 \cdot 4$ & 52 & $44 \cdot 1$ \\
\hline
\end{tabular}

eHCF, extensively hydrolysed casein-based formula.

a confirmed CMPA. The mean age was 4.2 months (minimum $1 \cdot 4$, maximum $6 \cdot 0$ ), and males represented $55 \%$ of included patients. The baseline characteristics of the study population included are summarised in Table 1 . At visit 1, the allergic symptoms on oral challenge with a CM formula were urticaria, worsening of atopic eczema/atopic dermatitis (AD) syndrome, vomiting, diarrhoea, physician-diagnosed wheezing or convincing behavioural symptoms. Among the 119 included infants, $54.2 \%$ had skin reactions; $33.9 \%$ had gastrointestinal reactions; $44.1 \%$ had subjective symptoms, such as crying and irritability; and $2.5 \%$ had airway reactions on oral challenge at visit 1 (Table 2). Among infants who had subjective symptoms, $32 \cdot 7 \%$ expressed also skin symptoms, $36.5 \%$ gastrointestinal symptoms and $1.9 \%$ airway reactions; $23 \cdot 1 \%$ had two or more other symptoms than subjective symptoms, and $9.6 \%$ expressed symptoms in two organ systems.

\section{Hypo-allergenicity/tolerance}

All the 193 screened infants were fed the eHCF for at least 4 weeks or more. All of them clinically tolerated the eHCF well, including the 119 infants who had an overt CMPA and could eventually be maintained in the follow-up, 6-month study.
During the following 6 months, eight subjects dropped out: five lost to follow-up; two consents retracted by the parents; one study formula stopped by the paediatrician. Of the 111 included infants who completed the 6-month feeding period, sixty-one became tolerant to $\mathrm{CM}$ and fifty were still allergic to $\mathrm{CM}$ at 6 months according to a DBPCFC.

At visit 3, among the fifty infants still allergic to CM, 59.2\% had skin reactions, $36.7 \%$ gastrointestinal reactions, $51 \cdot 0 \%$ subjective symptoms and $4 \cdot 1 \%$ airway reactions after the DBPCFC. Details of each item are described in Table 3. Among the infants who had subjective symptoms, $27 \cdot 8 \%$ expressed also skin symptoms, $77 \cdot 8 \%$ gastrointestinal symptoms and $5.6 \%$ airway reactions; $27.8 \%$ had two or more other symptoms than subjective symptoms, and $27 \cdot 8 \%$ expressed symptoms in two organ systems.

\section{Evolution of the scoring of atopic dermatitis index at 6 months}

The mean SCORAD index of infants fed the eHCF for 6 months significantly improved (Table 4), and decreased from 9.9 (SD 14.2) at randomisation to $5.6(\mathrm{SD} 9.5)$ at 6 months $(P<0 \cdot 001$, Wilcoxon's test). In the sub-population of infants with eczema (SCORAD $>0$ ), the SCORAD index decreased

Table 3. Symptoms that developed during double-blind, placebo-controlled food challenge at 6 months (visit 3) by still allergic infants

(Number of subjects and percentages)

\begin{tabular}{|c|c|c|c|c|c|c|c|}
\hline & & \multicolumn{2}{|c|}{ eHCF $(n 25)$} & \multicolumn{2}{|c|}{$\begin{array}{c}\text { eHCF }+ \\
\text { probiotics }(n 24)\end{array}$} & \multicolumn{2}{|c|}{ Total $(n 49)$} \\
\hline & & $n$ & $\%$ & $n$ & $\%$ & $n$ & $\%$ \\
\hline \multirow[t]{4}{*}{ Skin symptoms } & Urticaria & 4 & $16 \cdot 0$ & 3 & $12 \cdot 5$ & 7 & $14 \cdot 3$ \\
\hline & Rash & 16 & 64.0 & 9 & 37.5 & 25 & 51.0 \\
\hline & Pruritus & 1 & 4.0 & 3 & $12 \cdot 5$ & 4 & $8 \cdot 2$ \\
\hline & Eczema & 6 & $24 \cdot 0$ & 4 & $16 \cdot 7$ & 10 & 20.4 \\
\hline \multirow[t]{2}{*}{ Gastrointestinal symptoms } & Vomiting & 4 & $16 \cdot 0$ & 8 & 33.3 & 12 & 24.5 \\
\hline & Diarrhoea & 6 & $24 \cdot 0$ & 7 & $29 \cdot 2$ & 13 & $26 \cdot 5$ \\
\hline \multirow[t]{2}{*}{ Respiratory symptoms } & Sneezing & 1 & $4 \cdot 0$ & 0 & 0.0 & 1 & 2.0 \\
\hline & Wheezing & 0 & 0.0 & 1 & $4 \cdot 2$ & 1 & $2 \cdot 0$ \\
\hline Subjective symptoms (crying and irritability) & & 10 & $40 \cdot 0$ & 8 & 33.3 & 18 & $36 \cdot 7$ \\
\hline
\end{tabular}

eHCF, extensively hydrolysed casein-based formula. 
Table 4. The scoring of atopic dermatitis (SCORAD) index at randomisation and at 6 months

(Mean values and standard deviations)

\begin{tabular}{|c|c|c|c|c|c|c|c|c|c|}
\hline & \multirow[b]{2}{*}{ Treatments } & \multicolumn{2}{|c|}{ Randomisation } & \multicolumn{2}{|c|}{6 months } & \multicolumn{2}{|c|}{ Evolution } & \multirow[b]{2}{*}{$P$ (intra-group) } & \multirow[b]{2}{*}{$P$ (inter-group) } \\
\hline & & Mean & SD & Mean & SD & Mean & SD & & \\
\hline \multirow[t]{3}{*}{ All subjects included ( $n$ 110) } & eHCF & $9 \cdot 0$ & 12.9 & $5 \cdot 3$ & $8 \cdot 0$ & $-3 \cdot 7$ & $10 \cdot 3$ & $0.011^{\star}$ & $0.630 \dagger$ \\
\hline & eHCF + probiotics & $10 \cdot 9$ & $15 \cdot 5$ & $6 \cdot 0$ & $10 \cdot 8$ & -4.9 & $12 \cdot 5$ & $0.008^{\star}$ & \\
\hline & Total & $9 \cdot 9$ & $14 \cdot 2$ & $5 \cdot 6$ & 9.5 & $-4 \cdot 3$ & 11.4 & $<0.001^{\star}$ & \\
\hline \multirow[t]{3}{*}{ Subjects with SCORAD $>0(n 72)$} & eHCF & $15 \cdot 0$ & $13 \cdot 7$ & $8 \cdot 8$ & $8 \cdot 8$ & $-6 \cdot 2$ & $12 \cdot 8$ & $0.009 \ddagger$ & $0.836 \dagger$ \\
\hline & eHCF + probiotics & $15 \cdot 3$ & $16 \cdot 4$ & $8 \cdot 4$ & $12 \cdot 0$ & -6.9 & $14 \cdot 4$ & $0.008^{*}$ & \\
\hline & Total & $15 \cdot 2$ & $15 \cdot 1$ & $8 \cdot 6$ & $10 \cdot 6$ & $-6 \cdot 6$ & $13 \cdot 6$ & $<0.001^{*}$ & \\
\hline
\end{tabular}

eHCF, extensively hydrolysed casein-based formula.

* Wilcoxon's test.

†ANCOVA based on ranks.

$\ddagger$ Student's $t$ test.

significantly by -6.6 (SD 13.6; $P<0.001$ ). Probiotic supplementation to the eHCF had, however, no significant effect on the evolution of the SCORAD index.

\section{Anthropometric data}

At birth, the mean weight-for-age $z$ scores of included infants were all higher than $0 \cdot 0$ (Table 5). From birth to randomisation in the study, the mean weight-for-age $z$ scores decreased significantly by -1.5 (SD 1.1 ) in the entire study population, subgroup analysis showing no difference between the two groups.

Following the 6-month feeding of eHCF, a significant improvement was observed for the weight-for-age, lengthfor-age and weight-for-length $z$ scores, as well as restoration of a normal BMI (Table 6). Subgroup analyses did not show any benefit from the probiotic supplementation. In addition, proportions of infants with length-for-age and weight-for-age $z$ scores below $-2 \cdot 0$ were significantly reduced (Table 7 ). The distribution of $z$ scores for weight-for-age, length-for-age and weight-for-length at randomisation and after 6 months is shown in Figs. 2-4. At randomisation, the weight-for-age curve followed an expected dispersion but a deviation to the left. The length-for-age curve also showed a deviation to the left but a greater value of dispersion. The weight-forlength curve followed the expected dispersion but showed a slight deviation to the left. A 6-month feeding with the eHCF allowed normalisation of these three distributions.

\section{Discussion}

This post hoc analysis of the CAMEL study assessed, in a wellcharacterised population of infants with CMPA proved by oral challenge, the tolerance/hypo-allergenicity of the eHCF and its nutritional adequacy.

A total of 193 infants suspected of having CMPA were fed with the eHCF for at least 4 weeks. All of them, including the 119 infants with CMPA, clinically tolerated the eHCF well for 4 or more weeks, which is more than a sufficient period to detect late-onset allergic reactions according to the American Academy of Paediatrics ${ }^{(11)}$.

Previously published data mainly reported changes in the SCORAD index in infants fed an extensively hydrolysed whey-based formula. Previously, two studies have shown an improvement in this index after 6 and 8 months of extensively hydrolysed whey-based formula treatment ${ }^{(12,13)}$, as also observed in the present study after 6 months of eHCF feeding. These results are in opposition to those reported by Niggemann et $a l .{ }^{(14)}$. The SCORAD index results were registered at randomisation and after approximately 28, 60, 90 and $180 \mathrm{~d}$. They did not show any significant improvement and remained constant throughout the trial period. As already evidenced by the CAMEL study group in 2008, the probiotic supplementation had no effect on the evolution of the SCORAD index. Since 2008, Gore et al. $^{(15)}$ confirmed the lack of effect that probiotics have on eczema, as they found no benefit from supplementation with $B$. lactis or Lactobacillus paracasei in the treatment of eczema, in infants aged 3-6 months.

Table 5. Weight-for-age $z$ scores at birth and at randomisation (Mean values and standard deviations)

\begin{tabular}{|c|c|c|c|c|c|c|c|c|c|}
\hline \multirow[b]{2}{*}{ Treatments } & \multirow[b]{2}{*}{$n$} & \multicolumn{2}{|c|}{ Birth } & \multicolumn{2}{|c|}{ Randomisation } & \multicolumn{2}{|c|}{ Evolution } & \multirow[b]{2}{*}{$P$ (intra-group) } & \multirow[b]{2}{*}{$P$ (inter-group) } \\
\hline & & Mean & SD & Mean & SD & Mean & SD & & \\
\hline eHCF & 57 & 0.3 & $1 \cdot 2$ & $-1 \cdot 2$ & $1 \cdot 2$ & -1.5 & $1 \cdot 1$ & $<0.001^{*}$ & $z 0.679 \dagger$ \\
\hline eHCF + probiotics & 53 & 0.3 & $1 \cdot 0$ & $-1 \cdot 1$ & $1 \cdot 1$ & -1.5 & $1 \cdot 2$ & $<0.001 \ddagger$ & \\
\hline Total & 110 & 0.3 & $1 \cdot 1$ & $-1 \cdot 2$ & $1 \cdot 2$ & -1.5 & $1 \cdot 1$ & $<0.001 \ddagger$ & \\
\hline
\end{tabular}

eHCF, extensively hydrolysed casein-based formula

*Wilcoxon's test.

† ANCOVA based on ranks.

$\ddagger$ Student's $t$ test. 
Table 6. Anthropometric data at randomisation and at 6 months

(Mean values and standard deviations)

\begin{tabular}{|c|c|c|c|c|c|c|c|c|c|c|}
\hline & \multirow[b]{2}{*}{ Treatments } & \multirow[b]{2}{*}{$n$} & \multicolumn{2}{|c|}{ Randomisation } & \multicolumn{2}{|c|}{6 months } & \multicolumn{2}{|c|}{ Evolution } & \multirow[b]{2}{*}{$P$ (intra-group) } & \multirow[b]{2}{*}{$P$ (inter-group } \\
\hline & & & Mean & SD & Mean & SD & Mean & SD & & \\
\hline \multirow[t]{3}{*}{ Weight (kg) } & $\mathrm{eHCF}$ & 53 & 5.9 & $1 \cdot 4$ & 8.5 & $1 \cdot 2$ & $2 \cdot 6$ & $1 \cdot 1$ & $<0.001^{*}$ & $0.467 \dagger$ \\
\hline & eHCF + probiotics & 51 & $6 \cdot 0$ & $1 \cdot 2$ & $8 \cdot 6$ & $1 \cdot 1$ & $2 \cdot 7$ & 0.9 & $<0.001^{\star}$ & \\
\hline & Total & 104 & 5.9 & $1 \cdot 3$ & $8 \cdot 6$ & $1 \cdot 1$ & 2.6 & 1.0 & $<0.001^{\star}$ & \\
\hline \multirow[t]{3}{*}{ Weight-for-age $z$ score } & eHCF & 53 & $-1 \cdot 1$ & $1 \cdot 3$ & -0.5 & $1 \cdot 1$ & 0.6 & $1 \cdot 1$ & $<0.001^{\star}$ & $0.470 \dagger$ \\
\hline & eHCF + probiotics & 51 & $-1 \cdot 2$ & $1 \cdot 1$ & -0.4 & $1 \cdot 0$ & 0.8 & $1 \cdot 2$ & $<0.001 \ddagger$ & \\
\hline & Total & 104 & $-1 \cdot 2$ & $1 \cdot 2$ & -0.4 & 1.0 & 0.7 & $1 \cdot 2$ & $<0.001 \ddagger$ & \\
\hline \multirow[t]{3}{*}{ Length (cm) } & eHCF & 52 & $60 \cdot 2$ & $5 \cdot 4$ & 70.9 & 3.4 & $10 \cdot 6$ & 3.5 & $<0.001^{\star}$ & $0.995 \dagger$ \\
\hline & eHCF + probiotics & 49 & $60 \cdot 8$ & $4 \cdot 6$ & $71 \cdot 1$ & $3 \cdot 1$ & $10 \cdot 3$ & $3 \cdot 2$ & $<0.001^{*}$ & \\
\hline & Total & 101 & 60.5 & $5 \cdot 0$ & 71.0 & $3 \cdot 3$ & $10 \cdot 5$ & $3 \cdot 3$ & $<0.001^{*}$ & \\
\hline \multirow[t]{3}{*}{ Length-for-age $z$ score } & eHCF & 52 & $-1 \cdot 3$ & $1 \cdot 6$ & -0.8 & $1 \cdot 2$ & 0.4 & $1 \cdot 3$ & $0.021 \ddagger$ & $0.853 \dagger$ \\
\hline & eHCF + probiotics & 49 & $-1 \cdot 2$ & 1.4 & -0.9 & $1 \cdot 2$ & 0.3 & 1.5 & $0.104 \ddagger$ & \\
\hline & Total & 101 & $-1 \cdot 3$ & 1.5 & -0.9 & $1 \cdot 2$ & 0.4 & 1.4 & $<0.010 \ddagger$ & \\
\hline \multirow{3}{*}{$\begin{array}{l}\text { Weight-for-length } \\
\text { z score }\end{array}$} & $\mathrm{eHCF}$ & 52 & -0.1 & 0.9 & -0.3 & $1 \cdot 0$ & 0.1 & $1 \cdot 0$ & $0.611 \ddagger$ & $0.315 \dagger$ \\
\hline & eHCF + probiotics & 49 & 0.0 & 1.0 & 0.1 & 0.9 & 0.4 & 0.9 & $0.006 \ddagger$ & \\
\hline & Total & 101 & -0.2 & 1.0 & 0.0 & 0.9 & 0.2 & $1 \cdot 0$ & $<0.050 \ddagger$ & \\
\hline \multirow[t]{3}{*}{ BMI } & $\mathrm{eHCF}$ & 52 & $16 \cdot 1$ & 1.5 & $17 \cdot 0$ & 1.5 & 0.9 & 1.5 & $<0.001 \ddagger$ & $0.510 \dagger$ \\
\hline & eHCF + probiotics & 49 & $15 \cdot 9$ & $1 \cdot 6$ & $17 \cdot 0$ & $1 \cdot 3$ & $1 \cdot 1$ & 1.4 & $<0.001^{*}$ & \\
\hline & Total & 101 & $16 \cdot 0$ & 1.6 & $17 \cdot 0$ & 1.4 & $1 \cdot 0$ & 1.5 & $<0.001 \ddagger$ & \\
\hline \multirow[t]{3}{*}{ BMI-for-age $z$ score } & $\mathrm{eHCF}$ & 52 & -0.5 & 1.0 & 0.1 & 1.0 & 0.6 & $1 \cdot 0$ & $<0.001 \ddagger$ & $0.398 \dagger$ \\
\hline & eHCF + probiotics & 49 & -0.7 & 1.0 & 0.1 & 0.9 & 0.8 & 0.9 & $<0.001 \ddagger$ & \\
\hline & Total & 101 & -0.6 & $1 \cdot 0$ & 0.1 & $1 \cdot 0$ & 0.7 & $1 \cdot 0$ & $<0.001 \ddagger$ & \\
\hline
\end{tabular}

eHCF, extensively hydrolysed casein-based formula.

* Student's $t$ test.

†ANCOVA.

$\ddagger$ Wilcoxon's test.

Compared with healthy infants, infants with allergy can have impaired growth, which is partly attributable to improper food substitutions following allergen elimination ${ }^{(16)}$. Moreover, CMPA may also increase energy requirements through inflammation (i.e. skin or gastrointestinal) and disrupted sleep, as well as reduce the absorption of major nutrients (i.e. CMPA-induced enteropathy $)^{(17)}$. However, data on the nutritional adequacy of eHCF are insufficient ${ }^{(4)}$. Most of the published growth data were obtained in healthy term infants $^{(18-21)}$ or in infants at risk of atopy ${ }^{(22)}$ and very little in allergic infants, despite the fact that this type of formula is particularly targeted to the latter population. Only three previous trials have reported anthropometric indices in allergic infants fed an eHCF.
The post hoc analysis of growth data obtained in the CAMEL study ${ }^{(6)}$ provides interesting data on (1) the length and weight deficit affecting infants with CMPA and (2) the potential catch-up for both length and weight using an eHCF, thereby underlining its safe and nutritional adequacy for infants with CMPA.

Savino et al..$^{(5)}$ and Agostoni et al. ${ }^{(3)}$ showed a decrease in anthropometric indices between birth and inclusion in their study in infants with proved CMPA. In the Savino's study, twenty-six infants fed an eHCF were included at a mean age of 3.33 (sD 2.31) months. The mean weight-for-age $z$ scores of these infants were 0.04 (SD 0.79 ) at birth and decreased to -0.39 (sD 0.55) at 2.5 months of age, showing that CMPA induced a reduction in weight gain. Agostoni et al. ${ }^{(3)}$ reported that the mean weight-for-age $z$ scores was between $-0 \cdot 13$ and

Table 7. Proportions of infants with cows' milk protein allergy and nutritional deficits ( $z$ scores $<-2 \cdot 0$ ) (Number of subjects and percentages)

\begin{tabular}{|c|c|c|c|c|c|c|c|}
\hline & \multirow[b]{2}{*}{ Treatments } & \multicolumn{2}{|c|}{ Randomisation } & \multicolumn{2}{|c|}{6 months } & \multirow[b]{2}{*}{$P^{\star}$ (intra-group) } & \multirow[b]{2}{*}{$P \nmid$ (inter-group) } \\
\hline & & $n$ & $\%$ & $n$ & $\%$ & & \\
\hline \multirow{2}{*}{ Weight-for-age $z$ score } & eHCF+ probiotics & 13 & $25 \cdot 4$ & 2 & 3.9 & 0.004 & \multirow{2}{*}{0.455} \\
\hline & Total & 23 & $22 \cdot 1$ & 7 & $6 \cdot 8$ & 0.002 & \\
\hline \multirow[t]{2}{*}{ Length-for-age $z$ score } & eHCF & 15 & 28.9 & 7 & $13 \cdot 5$ & 0.032 & \multirow[t]{2}{*}{0.350} \\
\hline & Total & 32 & $31 \cdot 7$ & 14 & 13.9 & 0.002 & \\
\hline \multirow[t]{3}{*}{ Weight-for-length $z$ score } & eHCF & 1 & 1.9 & 0 & 0.0 & 0.317 & \multirow[t]{3}{*}{0.350} \\
\hline & eHCF + probiotics & 2 & $4 \cdot 1$ & 0 & 0.0 & 0.157 & \\
\hline & Total & 3 & $3 \cdot 0$ & 0 & 0.0 & 0.083 & \\
\hline
\end{tabular}

eHCF, extensively hydrolysed casein-based formula

* McNemar's test.

†Fisher's test. 
(a)

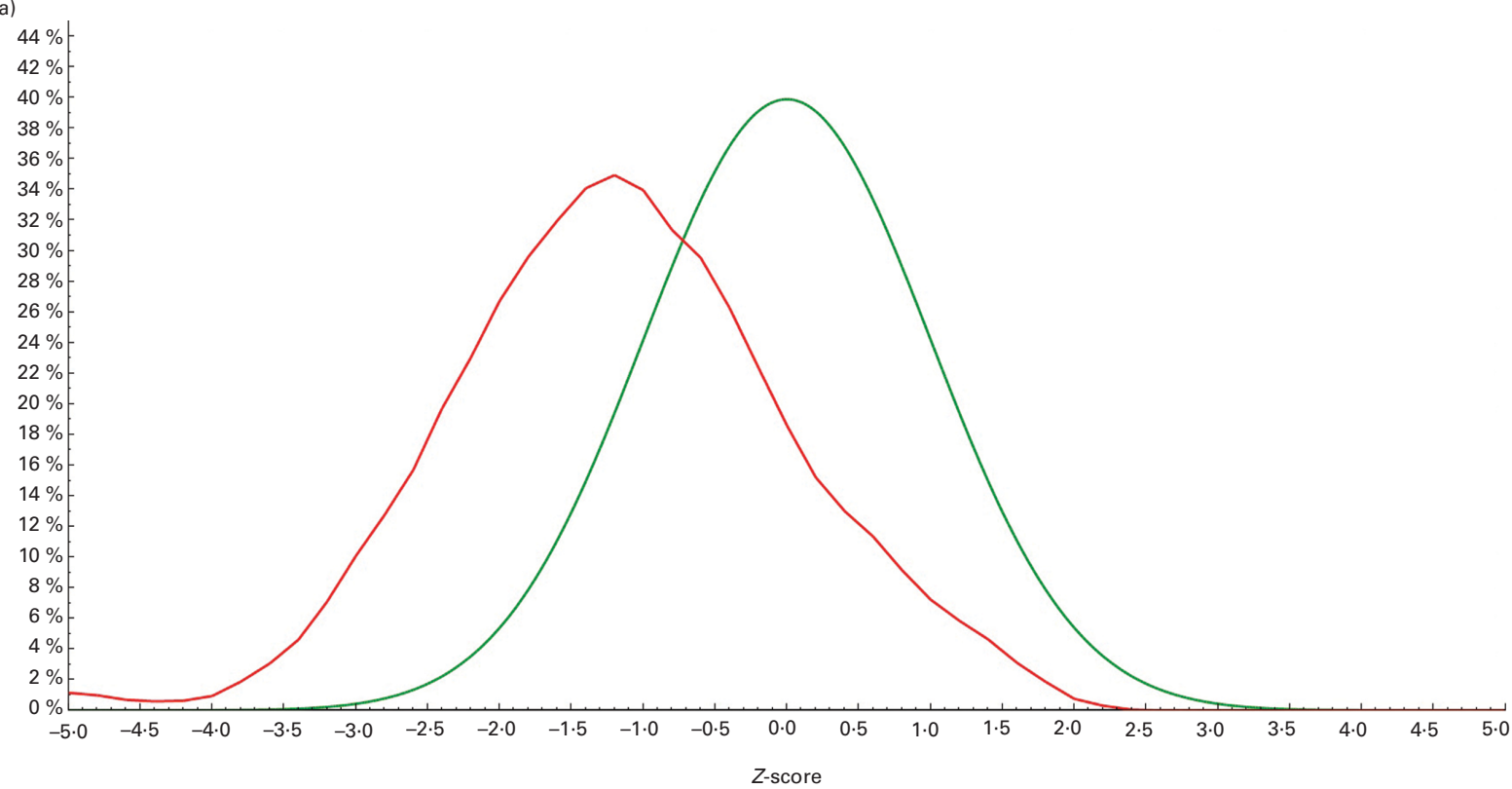

(b)

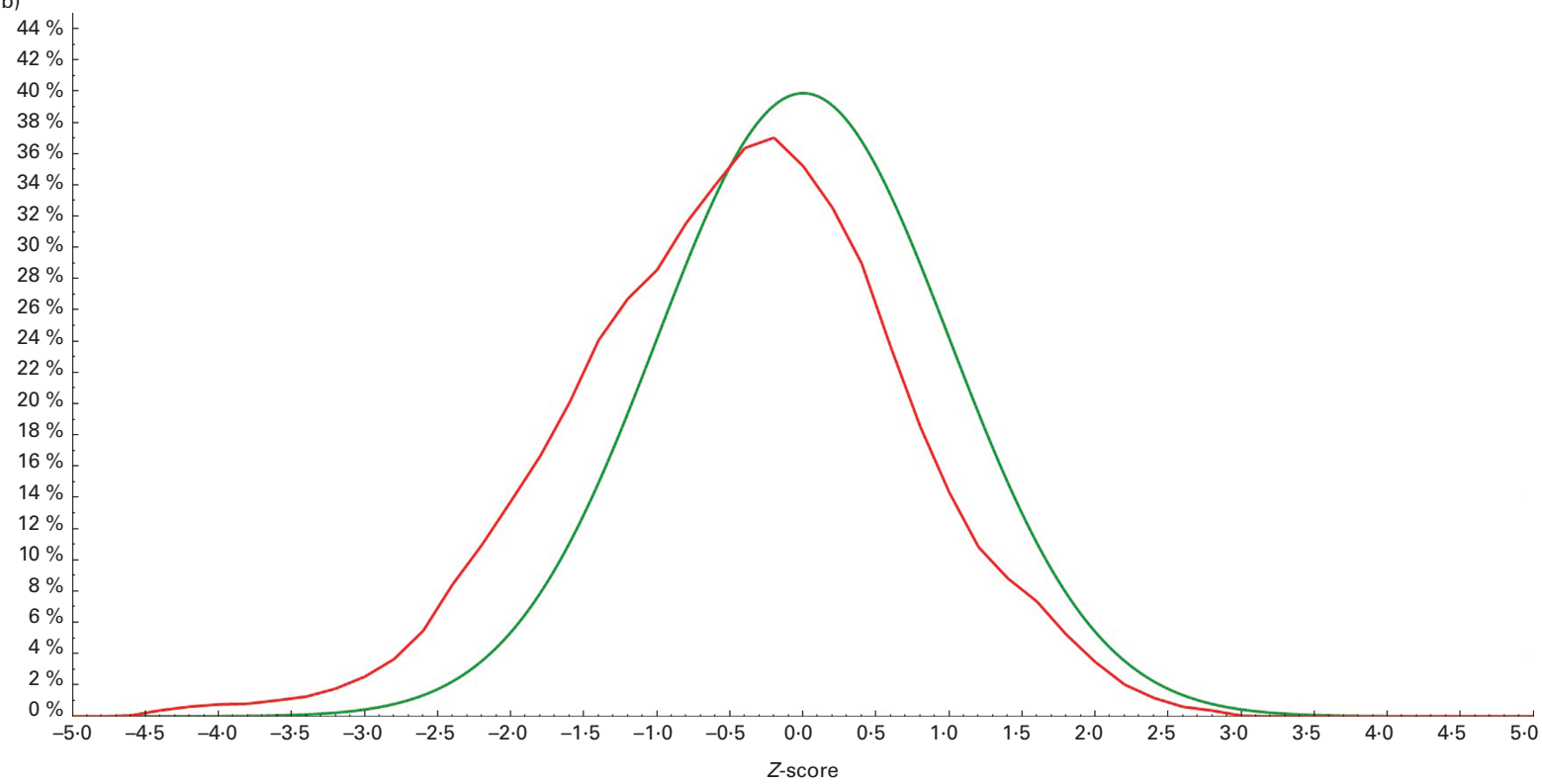

Fig. 2. Distribution of weight-for-age $z$ scores of all children $(-)$ compared with normal reference values $(-)$ at (a) randomisation and (b) after 6 months.

0.28 at birth, which decreased to -0.36 to -0.45 at 6 months of age. The same decrease in weight-for-age $z$ score between birth and study inclusion was observed in the present study. Because of the delay in diagnosis often seen in clinical practice, children with both immediate and delayed-type CMPA are particularly at risk of being undernourished ${ }^{(14)}$. Isolauri et $a l .{ }^{(16)}$ showed that the relative length and weight of infants with CMPA decreased compared with the control group. The decrease in relative length coincided with the onset of the symptoms suggestive of CMPA and the start of the elimination diet. The relative weight of children with CMPA continued to decrease compared with that in the non-allergic control group. In 2000, Agostoni et al. ${ }^{(23)}$ compared the growth of
114 healthy infants with that of fifty-five infants with AD in which thirty-eight showed positive reactivity to milk proteins. Subjects affected by $\mathrm{AD}$ showed a progressive impairment of growth both in weight-for-age and length-for-age $z$ scores. Differences between AD infants and healthy infants were significant from the second month of age onwards, more significantly in the second 6 months of life. More recently, Cho et al. ${ }^{(24)}$ showed in 165 subjects with $\mathrm{AD}$, of which seventy-seven were aged less than 12 months, that a higher number of sensitised food allergens was associated with negative effects on the growth and nutritional status of infants and young children with $\mathrm{AD}$. Meyer et al. ${ }^{(25)}$ assessed the growth status in ninety-seven food allergic children in the 
(a)

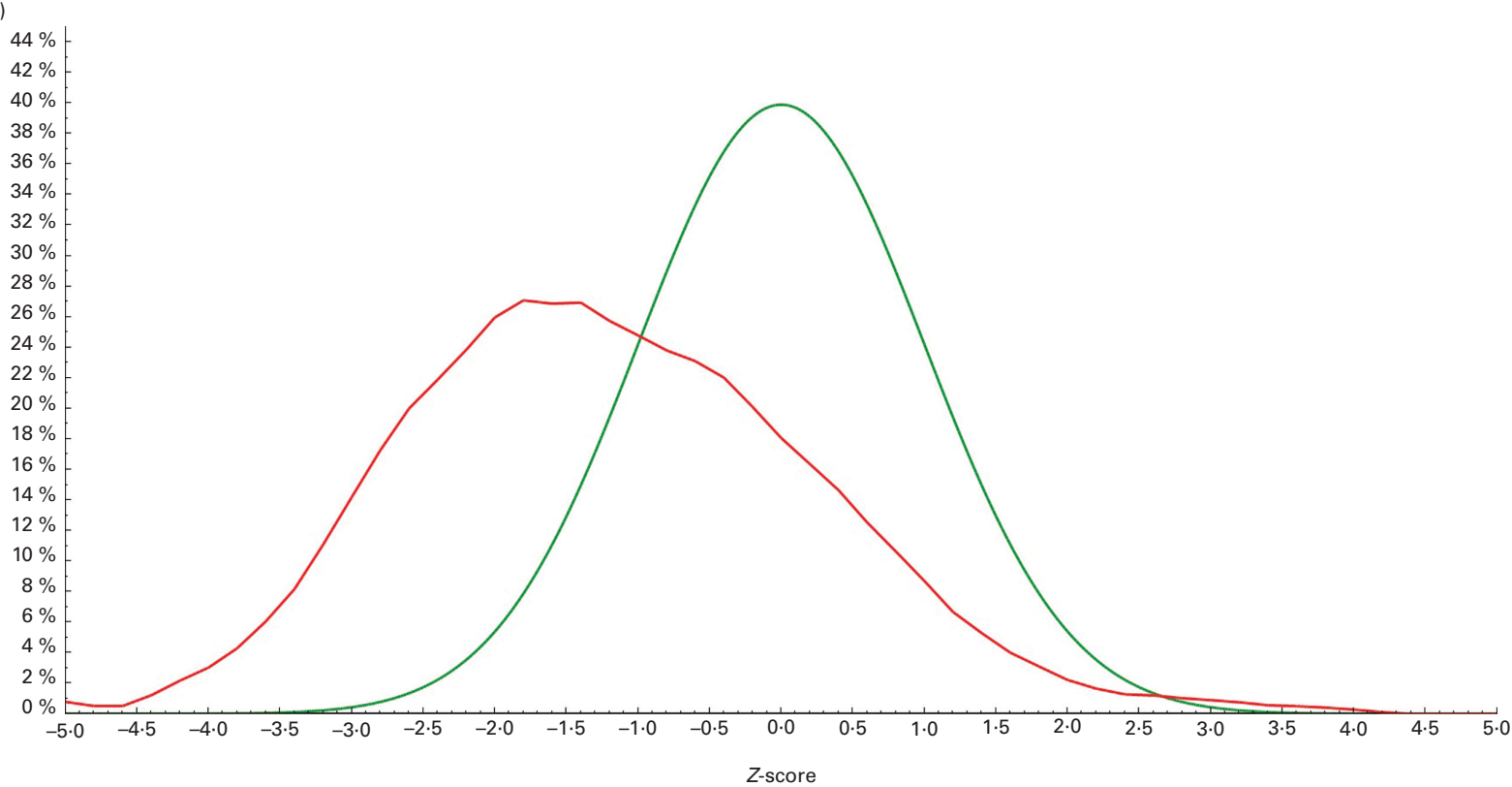

(b)

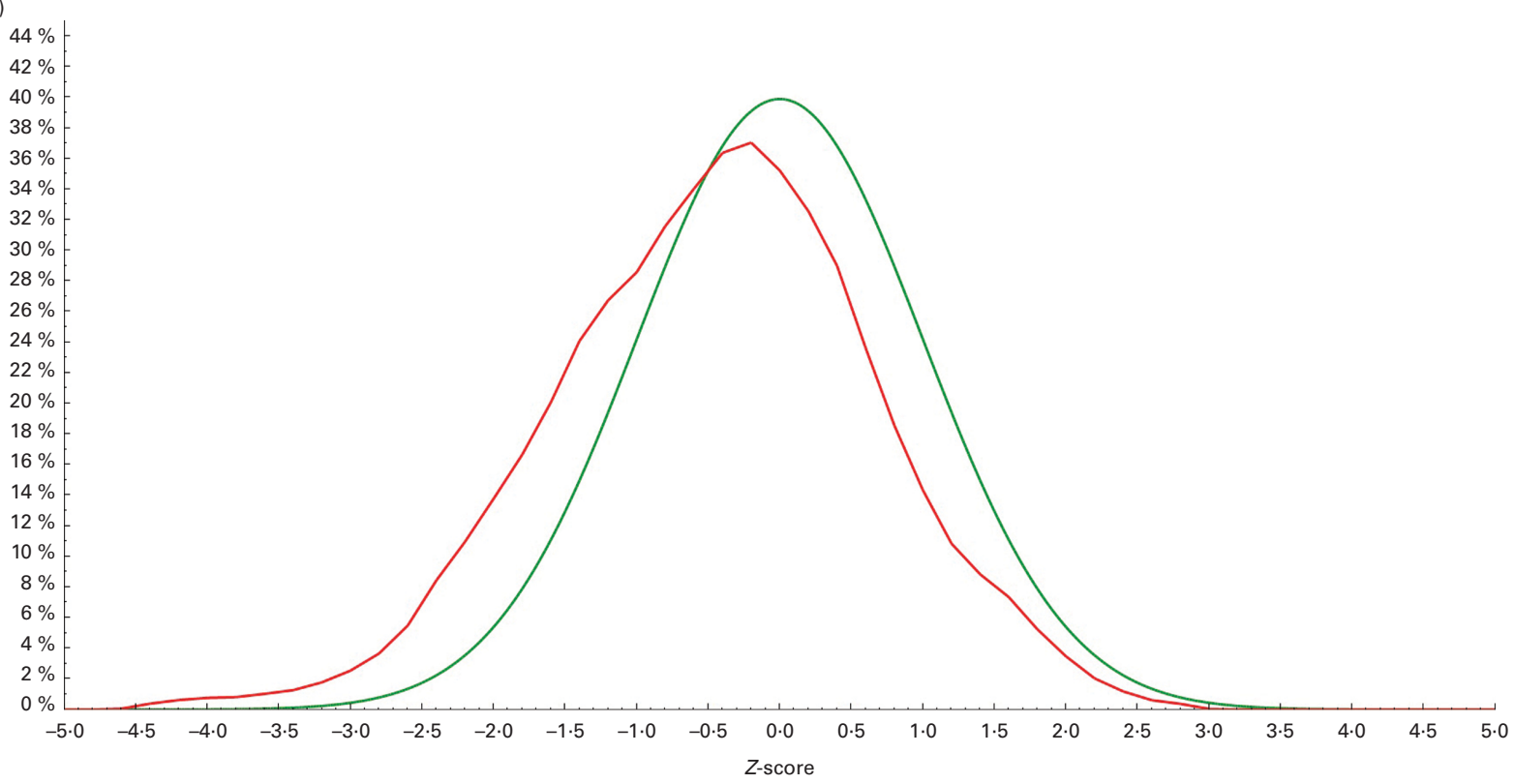

Fig. 3. Distribution of length-for-age $z$ scores of all children $(-$ ) compared with normal reference values $(-)$ at (a) randomisation and (b) after 6 months.

UK with a median (range) age of 27 (0.5-149) months. They found that elimination of more than three foods significantly affected the weight for age. Several other studies have shown growth deficit in infants with proved CMPA. Studies that have reported exact growth indices have been summarised in Table $8^{(3,5,13,26-28)}$. The growth indices obtained in the present study are similar to the previously published data. Vieira et $a l .{ }^{(29)}$ reported the prevalence percentages of severe malnutrition in infants with CMPA aged less than 6 months: $16 \cdot 5 \%$ for weight-for-age (underweight), $27 \cdot 8 \%$ for length-for-age (stunting) and $13.9 \%$ for weight-for-length $z$ scores (wasting) ${ }^{(30)}$. In the present study, the prevalence of underweight $(22 \cdot 1 \%)$ and stunted $(31.7 \%)$ children was higher, in contrast to wasted children $(3.0 \%)$, which was low in the CAMEL study.

Recently, the National Institute for Health and Clinical Excellence guidelines ${ }^{(31)}$ for food allergy in children and young people were updated by new evidence concerning the impact of food allergies on growth in babies and infants. The Italian Society of Paediatric Nutrition published a position statement concerning the nutritional management and followup of infants and children with food allergy ${ }^{(32)}$, showing an increased implication of scientific bodies in the assessment of physical growth in infants with CMPA.

Savino et ll $^{(5)}$ assessed the nutritional adequacy of a ricebased hydrolysed formula, compared with infants fed a soya 
(a) $44 \%$ -

$42 \%$ -

$40 \%-$

$38 \%$ -

$36 \%$ -

$34 \%$ -

$32 \%$ :-

$30 \%$ -

$28 \%$ -

$26 \%$ -

$24 \%$ -

$22 \%$ -

$20 \%$ -

$18 \%$ :

$16 \%$ :

$14 \%$ :

$12 \%$

$10 \%$ :

$8 \%$ :

$6 \%$ :

$4 \%$ :

$0 \%$

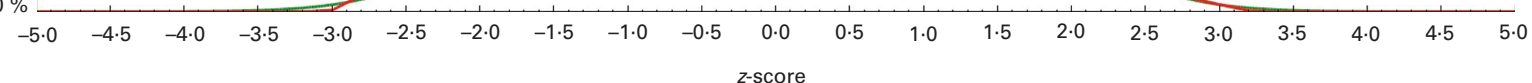

(b)

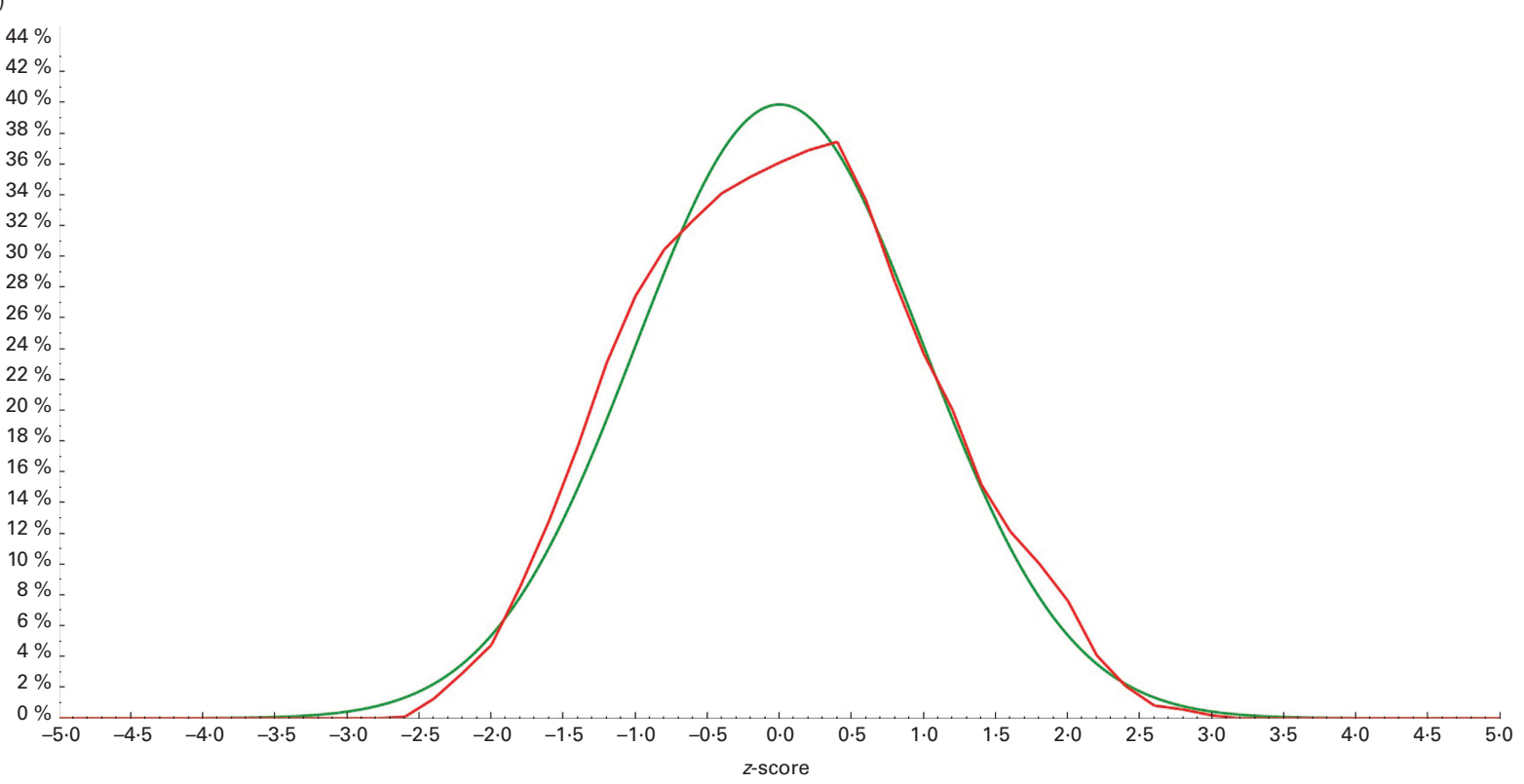

Fig. 4. Distribution of weight-for-length $z$ scores of all children (-) compared with normal reference values (-) at (a) randomisation and (b) after 6 months.

formula or an eHCF. The study evaluated the growth of fifty-eight infants with AD and CMPA (confirmed by an open challenge) who were fed either of these formulas during the first 2 years of life. The twenty-six infants fed the eHCF were included at a mean age of 3.33 (SD 2.31) months. Only weight-for-age $z$ scores were reported. All $z$ scores for infants fed the eHCF were higher than $-0 \cdot 6$. They increased between 2.5 and 5 months of age and from 7.5 to 24 months of age. In 2007, Agostoni et al. ${ }^{(3)}$ investigated in infants with CMPA whether the type of milk in the complementary feeding period (6-12 months of age) was associated with differences in the evolution of standardised growth indices (i.e. weightfor-age, length-for-age and weight-for-length $z$ scores).
For this, four feeding groups were compared, including one using a casein hydrolysate formula. Allergic infants ( $n$ 31), whose diagnosis was confirmed by a positive DBPCFC, were included between 5 and 6 months of age and fed an eHCF for 6 months. All $z$ scores increased during this period of time: from -0.44 to -0.27 for the weight-for-age $z$ score; from -0.40 to -0.16 for the length-for-age $z$ score; from $-0 \cdot 20$ to -0.12 for the weight-for-length $z$ score. BMI-forage $z$ scores were not reported. Recently, thirty-four allergic infants, aged less than 6 months, fed an eHCF showed a significant improvement in their weight-for-age $z$ score as of the first month of dietary treatment ${ }^{(27)}$. Altogether, these three studies and the present results, which are the largest 
Table 8. Summarised data relative to growth parameters in infants with cows' milk protein allergy (CMPA) at inclusion in the study (Mean values, standard deviations, number of subjects, percentages and $95 \%$ confidence intervals)

\begin{tabular}{|c|c|c|c|c|c|c|c|c|c|c|c|c|c|c|c|c|}
\hline & \multirow{2}{*}{$\begin{array}{l}\text { Treat- } \\
\text { ments }\end{array}$} & \multirow{2}{*}{$\begin{array}{l}\text { Number } \\
\text { of infants } \\
\text { included }\end{array}$} & \multicolumn{3}{|c|}{$\begin{array}{l}\text { Age of included } \\
\text { infants (months) }\end{array}$} & \multirow[b]{2}{*}{ CMPA diagnosis } & \multirow[b]{2}{*}{ Clinical characteristics } & \multicolumn{3}{|c|}{$\begin{array}{l}\text { Length-for-age } \\
z \text { scores }\end{array}$} & \multicolumn{3}{|c|}{$\begin{array}{l}\text { Weight-for-age } \\
z \text { scores }\end{array}$} & \multicolumn{3}{|c|}{$\begin{array}{l}\text { Weight-for-length } \\
z \text { scores }\end{array}$} \\
\hline & & & Mean & SD & $95 \% \mathrm{Cl}$ & & & Mean & SD & $95 \% \mathrm{Cl}$ & Mean & SD & $95 \% \mathrm{Cl}$ & Mean & SD & $95 \% \mathrm{Cl}$ \\
\hline $\begin{array}{l}\text { Isolauri et al. } \\
\qquad(1995)^{(13)}\end{array}$ & eHWF & 22 & 6 & NR & 4,7 & $\begin{array}{l}\text { Positive reactions } \\
\text { to a masked } \\
\text { challenge } \\
\text { with } \mathrm{CM}\end{array}$ & $\begin{array}{c}\text { Mean SCORAD index and } \\
\text { total IgE (IU/ml) values: } \\
21(95 \% \mathrm{Cl} 16,26) \text { and } \\
35(95 \% \mathrm{Cl} 11,115) \\
\text { Mean SCORAD index and } \\
\text { total IgE (IU/ml) values: } \\
17(95 \% \mathrm{Cl} 12,21) \text { and } \\
44(95 \% \mathrm{Cl} 12,158)\end{array}$ & -0.3 & NR & $-0.7,-0.01$ & & NR & & & NR & \\
\hline $\begin{array}{l}\text { De Boissieu \& } \\
\text { Dupont } \\
(2002)^{(26)}\end{array}$ & AAF & 52 & $5 \cdot 3$ & 3.8 & NR & $\begin{array}{l}\text { Adverse } \\
\text { reactions to } \\
\text { CM proteins }\end{array}$ & $\begin{array}{l}\text { Type of symptoms: diges- } \\
\text { tive symptoms: } n 47 \\
(90.4 \%), \text { eczema: } n 23 \\
(44.2 \%) \text {, failure to } \\
\text { thrive: } n 16(30.8 \%) \text {, } \\
\text { malaise: } n 8(15.4 \%) \\
\text { angio-oedema: } n 6 \\
\text { (11.5\%) }\end{array}$ & -0.86 & 1.37 & NR & -1.04 & 1.45 & NR & & NR & \\
\hline $\begin{array}{l}\text { Savino et al. } \\
(2005)^{(5)}\end{array}$ & eHCF & 26 & 3.33 & $2 \cdot 31$ & NR & $\begin{array}{l}\text { RAST, prick- } \\
\text { by-prick and } \\
\text { patch test and } \\
\text { confirmed by } \\
\text { food challenge }\end{array}$ & $\begin{array}{l}\text { Presence of atopic derma- } \\
\text { titis diagnosed by } \\
\text { Hanifin and Rajka } \\
\text { criteria (SCORAD index } \\
\text { values not reported) }\end{array}$ & & NR & & -0.39 & 0.55 & NR & & NR & \\
\hline $\begin{array}{l}\text { Agostoni et al. } \\
\qquad(2007)^{(3)}\end{array}$ & $\begin{array}{l}\text { SF } \\
\text { eHCF } \\
\text { eRHF } \\
\text { BF }\end{array}$ & $\begin{array}{c}32 \\
31 \\
30 \\
32\end{array}$ & 6 & & NR & $\begin{array}{l}\text { Food challenge } \\
\text { except in } \\
\text { children with } \\
\text { a history of } \\
\text { anaphylaxis }\end{array}$ & $\begin{array}{l}\text { Symptoms leading to the } \\
\text { second-level centres: } \\
\text { atopic eczema }(78.6 \%) \text {, } \\
\text { urticaria/angio-oedema } \\
(23 \cdot 1 \%) \text {, asthma and/or } \\
\text { rhinitis }(11.9 \%) \text {, gastro- } \\
\text { intestinal symptoms } \\
(8.6 \%) \text { and anaphylaxis } \\
(5.4 \%)\end{array}$ & $\begin{array}{l}-0.55 \\
-0.40 \\
-0.73 \\
-0.49\end{array}$ & NR & $\begin{array}{l}-0.81,-0.29 \\
-0.69,-0.10 \\
-1.00,-0.46 \\
-0.75,-0.24\end{array}$ & $\begin{array}{l}-0.45 \\
-0.44 \\
-0.41 \\
-0.36\end{array}$ & NR & $\begin{array}{l}-0.71,-0.19 \\
-0.74,-0.13 \\
-0.76,-0.06 \\
-0.63,-0.09\end{array}$ & $\begin{array}{l}-0.12 \\
-0.20 \\
0.04 \\
-0.01\end{array}$ & NR & $\begin{array}{l}-0.45,0.21 \\
-0.54,0.13 \\
-0.34,0.42 \\
-0.29,0.25\end{array}$ \\
\hline $\begin{array}{l}\text { Vandenplas } \\
\text { et al. } \\
(2014)^{(27)}\end{array}$ & eHCF & 34 & $86 \cdot 2^{*}$ & $38 \cdot 9^{*}$ & NR & $\begin{array}{l}\text { Positive food } \\
\text { challenge } \\
\text { to } \mathrm{CM}\end{array}$ & $\begin{array}{l}\text { Mean SBS: } 14 \cdot 3 \\
\quad(\text { SD 3.3) }\end{array}$ & -0.5 & $1 \cdot 4$ & NR & -0.6 & $1 \cdot 4$ & NR & -0.2 & 1.8 & NR \\
\hline $\begin{array}{l}\text { Vandenplas } \\
\text { et al. } \\
(2014)^{(28)}\end{array}$ & eHRF & 40 & 3.4 & 1.5 & NR & $\begin{array}{l}\text { Positive food } \\
\text { challenge } \\
\text { to } \mathrm{CM}\end{array}$ & $\begin{array}{l}\text { Mean SBS: } 13 \cdot 5 \\
\quad \text { (SD 5.2) }\end{array}$ & $\begin{array}{l}-0.1 \\
(n 37)\end{array}$ & 1.0 & NR & $\begin{array}{l}-0.7 \\
(n 38)\end{array}$ & 1.0 & NR & $\begin{array}{l}-0.7 \\
(n 37)\end{array}$ & 0.9 & NR \\
\hline $\begin{array}{l}\text { Dupont et al. } \\
\quad \text { (present } \\
\text { study) }\end{array}$ & eHCF & 119 & $4 \cdot 2$ & 1.4 & NR & $\begin{array}{l}\text { Positive food } \\
\text { challenge } \\
\text { to } \mathrm{CM}\end{array}$ & $\begin{array}{l}\text { Skin reactions, } 54.2 \% \text {; } \\
\text { gastrointestinal reac- } \\
\text { tions, } 33.9 \% \text {; subjective } \\
\text { symptoms, } 44.1 \% \text {; } \\
\text { airway reactions, } 2.5 \%\end{array}$ & $\begin{array}{l}-1 \cdot 3 \\
(n 101)\end{array}$ & & NR & $\begin{array}{l}-1 \cdot 2 \\
(n+104)\end{array}$ & $1 \cdot 2$ & NR & $\begin{array}{l}-0.2 \\
(n 101)\end{array}$ & 1.0 & NR \\
\hline
\end{tabular}

AAF, amino acid-based formula; NR, not reported; SCORAD, scoring of atopic dermatitis; eHWF, extensively hydrolysed whey-based formula; CM, cows' milk; eHCF, extensively hydrolysed casein-based formula; RAST, radioallergosorbent test; SF, soya formula; eHRF, extensively hydrolysed rice-based formula; BF, breast-feeding; SBS, symptom-based score ${ }^{(26,27}$. 
reported to date, showed improvement of anthropometric data in allergic infants fed an eHCF. This demonstrates that these formulas are nutritionally adequate for allergic infants. According to paediatric guidelines, food allergic children with severe growth faltering should be fed amino acid-based formulas as first-line dietary treatment ${ }^{(2,33-36)}$. Results from the present study showed that the eHCF was well tolerated and enabled a growth catch-up in food allergic infants with poor growth at randomisation and favour guidelines recommending amino acid-based formulas mainly in case of intolerance to extensively hydrolysed formulas.

Questions have been raised as to whether the probiotic supplementation could have an effect on weight gain or not ${ }^{(37)}$. Two recent meta-analyses conducted in healthy term infants have found that probiotics failed to significantly increase gains in weight, length and head circumference compared with the controls ${ }^{(38,39)}$. Results presented here also showed that the probiotic supplementation had no effect on growth in infants allergic to CM, irrelevant of the nutritional status of the infant at study inclusion.

\section{Conclusion}

The randomised, double-blind, placebo-controlled study by the CAMEL study group included 119 infants allergic to CM. All the 119 infants clinically tolerated the formula well during the 4-week period preceding the follow-on study, including the 111 infants fed the eHCF for at least 7 months. In addition, the SCORAD index improved significantly during this period of time.

Standardised growth indices ( $z$ scores) were evaluated at randomisation and after 6 months of eHCF feeding. These results show that this eHCF is safe, hypo-allergenic (according to the standards of the American Academy of Paediatrics: tolerance by at least $90 \%$ of CMPA infants with a 95\% CI) and nutritionally suitable for infants with CMPA.

\section{Acknowledgements}

The authors thank the infants, parents and physicians who kindly participated in the study.

The CAMEL study was funded by the Dutch Ministry of Economic Affairs. It had no role in the design and analysis of the present study or in the writing of this article.

The authors' contributions are as follows: C. D. participated in data analysis, drafting of the manuscript and final reviewing of the manuscript; J. H. and E. E. S. N. participated in the study design, data collection and final reviewing of the manuscript.

The authors declared that they have no conflicts of interest.

\section{References}

1. Vandenplas Y, Koletzko S, Isolauri E, et al. (2007) Guidelines for the diagnosis and management of cow's milk protein allergy in infants. Arch Dis Child 92, 902-908.

2. Koletzko S, Niggemann B, Arato A, et al. (2012) Diagnostic approach and management of cow's-milk protein allergy in infants and children: ESPGHAN GI Committee practical guidelines. J Pediatr Gastroenterol Nutr 55, 221-229.
3. Agostoni C, Fiocchi A, Riva E, et al. (2007) Growth of infants with IgE-mediated cow's milk allergy fed different formulas in the complementary feeding period. Pediatr Allergy Immunol 18, 599-606.

4. Dupont C, Chouraqui JP, de Boissieu D, et al. (2011) Dietetic treatment of cow's milk protein allergy. Arch Pediatr 18, 79-94.

5. Savino F, Castagno E, Monti G, et al. (2005) Z-score of weight for age of infants with atopic dermatitis and cow's milk allergy fed with a rice-hydrolysate formula during the first two years of life. Acta Paediatr Suppl 94, 115-119.

6. Hol J, van Leer EH, Elink Schuurman BE, et al. (2008) The acquisition of tolerance toward cow's milk through probiotic supplementation: a randomized, controlled trial. J Allergy Clin Immunol 121, 1448-1454.

7. Bock SA, Sampson HA, Atkins FM, et al. (1988) Double-blind, placebo-controlled food challenge (DBPCFC) as an office procedure: a manual. J Allergy Clin Immunol 82, 986-997.

8. Bruijnzeel-Koomen C, Ortolani C, Aas K, et al. (1995) Adverse reactions to food. European Academy of Allergology and Clinical Immunology Subcommittee. Allergy 50, 623-635.

9. Consensus Report of the European Task Force on Atopic Dermatitis (1993) Severity scoring of atopic dermatitis: the SCORAD index. Dermatology 186, 23-31.

10. WHO Multicentre Growth Reference Study Group (2006) WHO Child Growth Standards: Length/Height-for-age, Weight-for-age, Weight-for-length, Weight-for-height and Body Mass Index-for-age: Methods and Development. Geneva: World Health Organization.

11. American Academy of Pediatrics (2000) Committee on Nutrition. Hypoallergenic infant formulas. Pediatrics 106, 346-349.

12. Niggemann B, Binder C, Dupont C, et al. (2001) Prospective, controlled, multi-center study on the effect of an amino-acidbased formula in infants with cow's milk allergy/intolerance and atopic dermatitis. Pediatr Allergy Immunol 12, 78-82.

13. Isolauri E, Sütas Y, Mäkinen-Kiljunen S, et al. (1995) Efficacy and safety of hydrolyzed cow milk and amino acid-derived formulas in infants with cow milk allergy. $J$ Pediatr 127, $550-557$.

14. Niggemann B, von Berg A, Bollrath C, et al. (2008) Safety and efficacy of a new extensively hydrolyzed formula for infants with cow's milk protein allergy. Pediatr Allergy Immunol 19, 348-354.

15. Gore C, Custovic A, Tannock GW, et al. (2012) Treatment and secondary prevention effects of the probiotics Lactobacillus paracasei or Bifidobacterium lactis on early infant eczema: randomized controlled trial with follow-up until age 3 years. Clin Exp Allergy 42, 112-122.

16. Isolauri E, Sutas Y, Salo MK, et al. (1998) Elimination diet in cow's milk allergy: risk for impaired growth in young children. J Pediatr 132, 1004-1009.

17. Meyer R, Venter C, Fox AT, et al. (2012) Practical dietary management of protein energy malnutrition in young children with cow's milk protein allergy. Pediatr Allergy Immunol 23, 307-314.

18. Hernell O \& Lönnerdal B (2003) Nutritional evaluation of protein hydrolysate formulas in healthy term infants: plasma amino acids, hematology, and trace elements. $A m J$ Clin Nutr 78, 296-301.

19. Burks W, Jones SM, Berseth CL, et al. (2008) Hypoallergenicity and effects on growth and tolerance of a new amino acid-based formula with docosahexaenoic acid and arachidonic acid. J Pediatr 153, 266-271. 
20. Mennella JA, Ventura AK \& Beauchamp GK (2011) Differential growth patterns among healthy infants fed protein hydrolysate or cow-milk formulas. Pediatrics 127, 110-118.

21. Borschel MW, Baggs GE \& Barrett-Reis B (2014) Growth of healthy term infants fed ready-to-feed and powdered forms of an extensively hydrolyzed casein-based infant formula: a randomized, blinded, controlled trial. Clin Pediatr (Phila) 53, 585-592.

22. Rzehak P, Sausenthaler S, Koletzko S, et al. (2009) Short- and long-term effects of feeding hydrolyzed protein infant formulas on growth at $<$ or $=6$ y of age: results from the German Infant Nutritional Intervention Study. Am J Clin Nutr 89, 1846-1856.

23. Agostoni C, Grandi F, Scaglioni S, et al. (2000) Growth pattern of breastfed and nonbreastfed infants with atopic dermatitis in the first year of life. Pediatrics 106, E73.

24. Cho HN, Hong S, Lee SH, et al. (2011) Nutritional status according to sensitized food allergens in children with atopic dermatitis. Allergy Asthma Immunol Res 3, 53-57.

25. Meyer R, De Koker C, Dziubak R, et al. (2014) Malnutrition in children with food allergies in the UK. J Hum Nutr Diet 27, 227-235.

26. de Boissieu D \& Dupont C (2002) Allergy to extensively hydrolyzed cow's milk proteins in infants: safety and duration of amino acid-based formula. J Pediatr 141, 271-273.

27. Vandenplas Y, De Greef E \& ALLAR study group (2014) Extensive protein hydrolysate formula effectively reduces regurgitation in infants with positive and negative challenge tests for cow's milk allergy. Acta Paediatr 103, e243-e250.

28. Vandenplas Y, De Greef E, Hauser B \& Paradice Study Group (2014) Safety and tolerance of a new extensively hydrolyzed rice protein-based formula in the management of infants with cow's milk protein allergy. Eur J Pediatr 173, 1209-1216.

29. Vieira MC, Morais MB, Spolidoro JV, et al. (2010) A survey on clinical presentation and nutritional status of infants with suspected cow' milk allergy. BMC Pediatr 10, 25.

30. World Health Organization, Working group on Infant Group Nutrition Unit (1995) An evaluation of infant growth: the use and interpretation of anthropometry in infants. Bull WHO 73, $165-174$.

31. NICE Guidelines (2012) Food allergy in children and young people: Evidence Update May 2012 - A summary of selected new evidence relevant to NICE clinical guideline 116 'Diagnosis and assessment of food allergy in children and young people in primary care and community settings' (2011). http://www.evidence.nhs.uk/ (accessed February 2015).

32. Giovannini M, D'Auria E, Caffarelli C, et al. (2014) Nutritional management and follow up of infants and children with food allergy: Italian Society of Pediatric Nutrition/Italian Society of Pediatric Allergy and Immunology Task Force Position Statement. Ital J Pediatr 40, 1.

33. Fiocchi A, Brozek J, Schünemann H, et al. (2010) World Allergy Organization (WAO) diagnosis and rationale for action against cow's milk allergy (DRACMA) guidelines. World Allergy Organ J 3, 57-161.
34. Venter C, Brown T, Shah N, et al. (2013) Diagnosis and management of non-IgE-mediated cow's milk allergy in infancy a UK primary care practical guide. Clin Transl Allergy 3, 23.

35. Luyt D, Ball H, Makwana N, et al. (2014) BSACI guideline for the diagnosis and management of cow's milk allergy. Clin Exp Allergy 44, 642-672.

36. Muraro A, Werfel $\mathrm{T}$, Hoffmann-Sommergruber $\mathrm{K}$, et al. (2014) EAACI food allergy and anaphylaxis guidelines: diagnosis and management of food allergy. Allergy $\mathbf{6 9}$, $1008-1025$.

37. Million M, Angelakis E, Paul M, et al. (2012) Comparative meta-analysis of the effect of Lactobacillus species on weight gain in humans and animals. Microb Pathog 53, 100-108.

38. Mugambi MN, Musekiwa A, Lombard M, et al. (2012) Synbiotics, probiotics or prebiotics in infant formula for full term infants: a systematic review. Nutr $J \mathbf{1 1}, 81$.

39. Szajewska H \& Chmielewska A (2013) Growth of infants fed formula supplemented with Bifidobacterium lactis Bb12 or Lactobacillus GG: a systematic review of randomized controlled trials. BMC Pediatr 13, 185.

\section{Appendix: CAMEL Study Group}

Johan C. de Jongste, MD, PhD, Janneke N. Samsom, PhD, Eduard H. G. van Leer, MD, PhD, Beatrix E. E. Elink Schuurman, MScN, Lilian F. de Ruiter, Herman J. Neijens, MD, PhD.

\section{Investigators in participating hospitals}

F. G. A. Versteegh (Groene Hart Ziekenhuis, Gouda, The Netherlands), M. Groeneweg (Medisch Centrum Rijnmond Zuid, Rotterdam, The Netherlands), L. N. van Veen (Reinier de Graaf Groep, Delft, The Netherlands), A. A. Vaessen-Verberne (Amphia Ziekenhuis, Breda, The Netherlands), M. J. M. Smit (Juliana Kinderziekenhuis, Den Haag, The Netherlands), A. W. Vriesman and Y. M. Roosen (Albert Schweitzer Ziekenhuis, Dordrecht, The Netherlands) and G. L. den Exter (Vlietland, Schiedam, The Netherlands).

\section{Healthy baby clinics}

Consultatieburo Ouder \& Kind (Rotterdam, The Netherlands), Vierstroom Zorgring (Gouda and Zoetermeer, The Netherlands), Maatzorg (Delft and Spijkenisse, The Netherlands), Thuiszorg Breda (Breda, The Netherlands), Stichting Opmaat (Zwijndrecht, The Netherlands), Thuiszorg Mark en Maasmond (Oosterhout, The Netherlands), Thuiszorg Nieuwe Waterweg Noord (Maassluis, The Netherlands), Thuiszorg De Zellingen (Capelle aan den IJssel, The Netherlands), and Thuiszorg West-Brabant (Roosendaal, The Netherlands). 